\title{
熱尖端流を用いた凍結乾燥促進に関する研究*
}

\author{
北村雅 裕 ${ }^{* 1}$, 蔦原 道 久*2, 田口智清*3 \\ 三谷亮介*4, 榎村畺 ${ }^{* 5}$, 張 暁 峰*5
}

\section{A Study of Promotion of Sublimation Phenomenon of Freeze Drying by Using Thermal Edge Flow}

\author{
Masahiro KITAMURA, Michihisa TSUTAHARA*6, Satoshi TAGUCHI, \\ Ryousuke MITANI, Masakazu ENOMURA and XiaoFeng ZHANG
}

\author{
${ }^{* 6}$ Graduate School of Engineering, Kobe University, \\ 1-1 Rokkodaicho, Nada-ku, Kobe-shi, Hyogo, 657-8501 Japan
}

\begin{abstract}
A blower driven by the thermal edge flow was shown to promote the freeze-drying processes. First, the pressure rise due to the thermal edge flow was confirmed by using an accumulation unit and the pressure rise of $5 \mathrm{~Pa}$ was obtained. Next, the effect of the blower for sublimation from frozen material was confirmed by using frozen sponges containing some amount of water. The necessary time for drying by using the blower was roughly half of that without the blower, and the efficiency of the sublimation was shown to depend on the combination of the effects of the blower and the surrounding vacuum pressure.
\end{abstract}

Key Words : Rarefied Gas, Thermal Edge Flow, Blower, Vaccum, Sublimation, Freeze Drying

\section{1. 粕言}

低圧下で温度公配を持っ平板では, 平板に沿って高温 側に向かった流れが誘起される.この流れは，熱まふく 流 ${ }^{(1)}$ （3) と呼ばれる. また, 温度勾配のない均一に熱 せられた平板の緑部（エッシ）においてもエッジ部付近 の気体に温度公配が生じるため，熱まふく流と同様にエ ッジに向かう流れが誘起される.これか熱尖端流 ${ }^{(4)}$ （8) と呼ばれる流れである. 両側に縁を持つ平板の場合，両 縁て誘起される熱尖端流は相殺し，全体としては一方向 に気体を輸送することはできない，杉元らはこの熱尖端 流の工学的炕用として, 高温の平板と低温の平板を交互 に設置することにより，一方向に流れるポンプを提案し ている ${ }^{(7)}{ }^{(8)}$. 本研究では平板の一方の縁部を筒状に 丸く曲げその縁部て熱尖端流が生じないようにすること で，加熱平板で一方向の流れを実現し，この丸めた筒状

* 原稿受付 2008 年 10 月 27 日.

*1 神戸大学大学院自然科学研究科(㤲657-8501 神戸市灘区六 甲台町 1-1)

*2 正員, フェロー, 神戸大学大学院工学研究科.

*3 神戸大学自然科学系先端融合研究環.

*4 神戸大学大学院工学研究科.

*5 正員, エム・テクニック(株) (五594-1144 和泉市テクノス テージ 2-2-16).

E-mail : tutahara@mech.kobe-u.ac.jp
の内部に平板を加熱するヒーターを組み込んた熱尖端流 を利用した送風器を製作した。

一方凍結乾燥は，加熱による被乾燥対象一影響の少な い乾燥手段として医薬品や食品などの多くの分野で広く 用いられている ${ }^{(9)} \sim(11)$. 凍結乾燥装置には, 真空槽 内に昇華により生じた蒸気を低温により再度凍結させ真 空度を保つためのコールドトラップか設置されており， 乾燥初期には被乾燥対象からトラップへの気流が生じる. しかし乾嬠の最終段階で蒸気の発生も少なく, コール ドトラップへの気流も弱くなる. すなわち, 被乾燥対象 からの蒸気を蛑的に送り出寸メカニズムが㗢かなくな ることから, 蒸気の境界層が形成され昇華が妨げられる と考えられる.この段階て蒸気を含まない乾燥した気流 を被乾燥対象に当てることで, 最終段階での乾燥を促准 することが可能であるが，現在の装置においてこの目的 で送風器が設置されたものは見当たらない.

そこで熱尖端流を利用した送風器を, この凍結乾燥の 送風機能として用いることで昇華速度を上昇させ, 乾燥 を促進するのが本研究の目的である. 本提案の送風器は， 一切の可動部分がなく, 構造が単純であるだけでなく, 運軽に際しても後述するようにヒーターに通電するのみ である. また可動部がないことから，一切の潤滑を必要 
とせず，真空槽内执よひ被倝燥対象を污染することがな い.

熱尖端流を利用した送風器での一方向の流れを確認 するためにます熱尖端流により送風器下流の圧力が上 昇することを確認した. 次にこの送風器の凍結乾㷘促進 効果の確認として，水を含ませたスポンジの凍結物を用 いて真空槽内て乾燥の実験を行い，乾燥に必要な時間が 約半分に促倠されることを確認した．また熱尖端流を利 用した送風器の稼動する真空槽内の圧力が高、場合の方 がスポンジの乾燥が早くなることを確認した，2章で昇 圧碓認について実験力法およびその実験結果を，3章で 凍結乾燥実験について実験力法およびその実験結果を説 明する.

\section{2. 熱尖端流を利用した送風器による昇圧実験}

熱尖端流を利用した送風器により生じる気流の風速 を直接測定することは，低圧下での気流を測定すること となり，常圧下で行われる方法(たとえば熱線流速計ある いはレーザードプラー流速計など)は使用できない.低圧 下での測定としては，手島ら (1 2) がレーザー蛍光を用 いて流速測定を行っているが, きわめて高速の気流 (超 音速) の適用のみで, 今回のような数十 $\mathrm{m} / \mathrm{s}$ の流孔に 対して適用できない. 曾根ら ${ }^{(1)}{ }^{(5)}$ は, 軽量のファン を製作し熱ほふく流の確認に用いたが，流速等の定 量的な測定ではない。

本実験では流束測定に替わる力法として, 送風器下流 での圧力上昇を計測する実験を行った．送風器の下流を せき止めることにより上昇した圧力により，上流力向一 流れが生じるが、これか熱尖端流とつりあうこととなる。

$2 \cdot 1$ 実洗置長さ $185 \mathrm{~mm}$, 幅 $65 \mathrm{~mm}$, 高さ 185 $\mathrm{mm}$ の L 字状の一端を開放し他端を閉止した容器に，そ の入口部分に厚さ $0.3 \mathrm{~mm}$ の鋾板て製作した，一方の縁 部を筒状に丸めたプレート複数枚を，一定の間隔で多段 に取り付けた. プレートの加熱のために各プレートの筒 状の中空部に，プレート錋板と絶縁してニクロム線の七 一ターを設けた。容器の閉止端には, 容器内部の圧力 を計測するためのピラニー真空計を取り付けた．図 1 に 実験装置の構造を示す。

実験はプレートの形狱・枚数の異なる二つのケースで 行った. Case 1 の場合には，長さ $90 \mathrm{~mm}$, 幅 $48 \mathrm{~mm} の$ プレー 2 枚を図 1 に示す様に プレート間隔 $17 \mathrm{~mm}$ で 上下 2 段に取り付けた。 またCase 2 の場合は，長さ $50 \mathrm{~mm}$, 幅 $60 \mathrm{~mm}$ のプレート 6 枚を前後の院間 $10 \mathrm{~mm}$ で 2 列に し，プレート上下の間隔 $10 \mathrm{~mm}$ の3段に設けて実験を行 った.

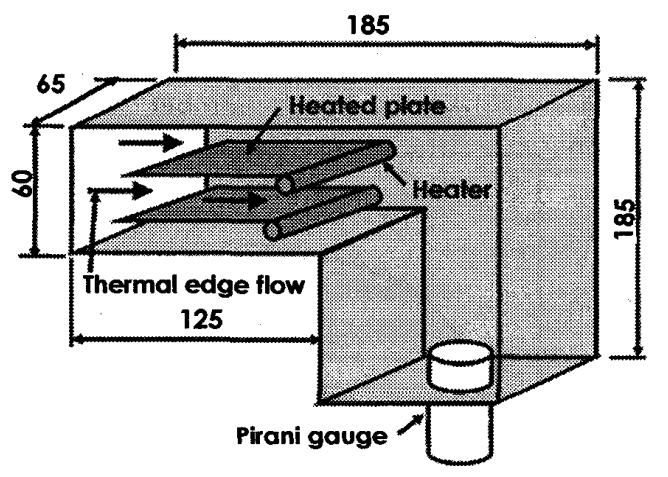

Fig. 1 Accumulation unit with heated plates that induce the thermal edge flow.

2 -2 実銿方法 縦，横，奥行き各 $450 \mathrm{~mm}$ ，容積 約 $0.09 \mathrm{~m}^{3}$ の矩形の真空槽内に図 1 の容器を設置し, 真空 槽内の圧力を真空ポンプにより下げ，圧力が $90 \mathrm{~Pa} に$ 到 達後に真空ポンプを停止し実験を開始した，真空槽内に も, 真空槽内の圧力を計測するピラニ一真空計を設置し た. 真空ポンプの停止と同時にプレートのヒーターの加 熱を開始し、プレートのヒーター部温度, プレートのヒ 一タ一部と反刘側縁部温度およひ傎空槽内の温度の計測 および真空槽内の圧力と容器就部の圧力の計測を行う.

これらの計測は真空槽内の圧力が, 真空槽のシールから の漏れにより約 $400 \mathrm{~Pa}$ に上昇するまで行った.

容器端部の圧力と真空槽内の圧力との圧力差が, 容器 内部の圧力上昇分となる. 本実験の計敗範囲でのピラニ 一真空計の測定精度は土15\%であり事前に計貺範用での 両真空計の誤差の確認を行い㽵力上昇結果 $の$ 修正を行っ ている.

\section{$2 \cdot 3$ 実険恄果及ひ考察}

2.3.1 各部淐度变化 Case 1での実験中のプレ 一トヒーター部の温度, ヒーターと反対側のプレート縁 部の温度および真空槽内での温度の時間変化を, 図 2 に 示す. 実験終了時にはプレートヒーター部の温度は $240^{\circ} \mathrm{C}$ まで上昇し, またプレート縁部の温度は $150^{\circ} \mathrm{C}$ まで 上昇している. 一方真空槽の内部の温度は実験を通して 約 $20^{\circ} \mathrm{C}$ て安定している.

2-3-2 圧力上昇 Case 1, Case 2 の実験で得られ た容器内下流部での上昇圧力と, 真空槽内珐力の関係を 図3に示寸。図はCase 1 およびCase 2 で各 3 回実施し た平均を示している.

Case 1, Case 2 何れの場合にも容器内下流部での上昇 圧力は，真空槽内の圧力の上昇に伴、徐々に上昇し真空 槽内の圧力が $300 \mathrm{~Pa}$ をピークとして降下寸る. これは真 空槽内の圧力の上昇に伴、容器内一の流れ，すなわち熱 


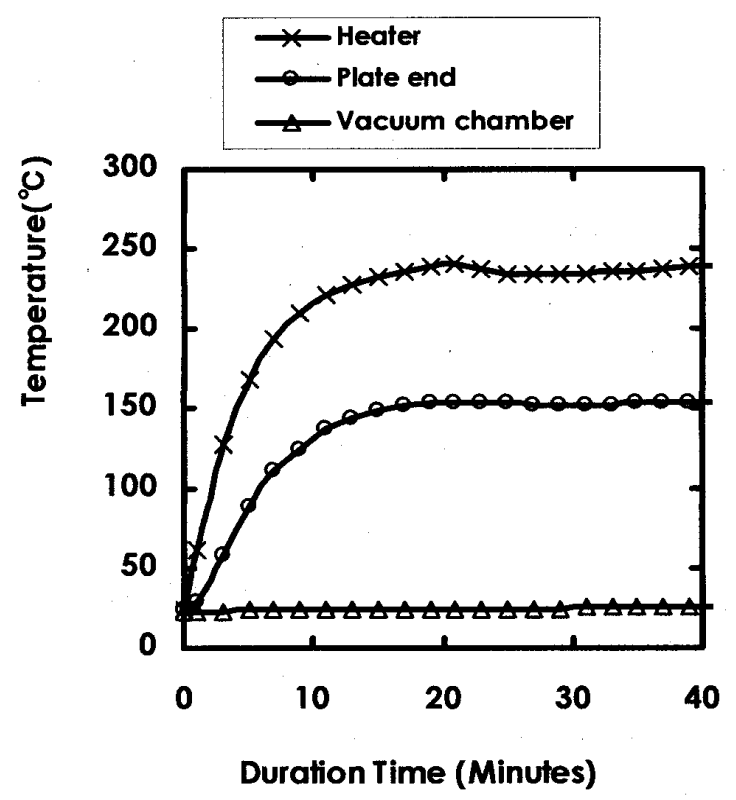

Fig. 2 Temperature histories in the case of two plates $(90 \mathrm{~mm}$ in length and $48 \mathrm{~mm}$ in width each; Case 1) installed in the accumulation unit. Measuring points: (1) heater of the heated plate, (2) the opposite side of heated plate, and (3) the vacuum chamber.

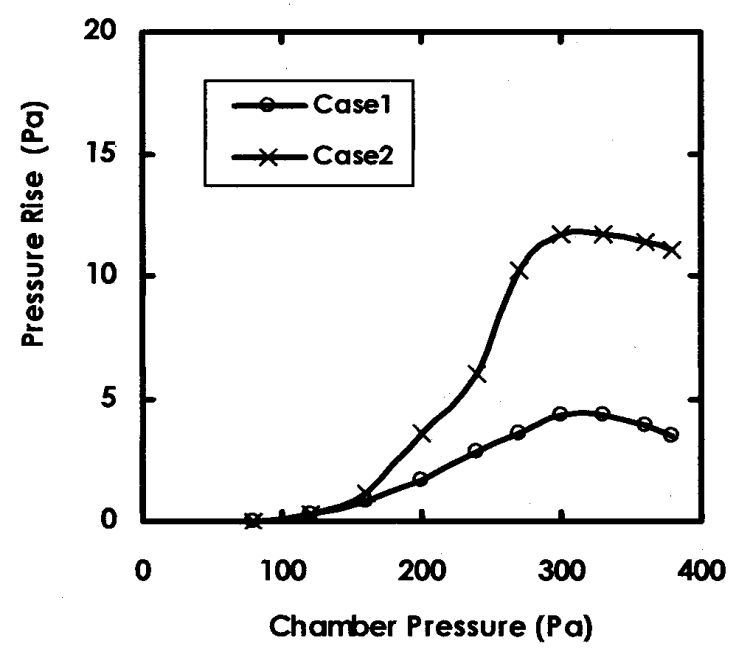

Fig. 3 Pressure rise in the accumulation unit vs. the pressure in the vacuum chamber. Two plates $(90 \mathrm{~mm}$ in length and $48 \mathrm{~mm}$ in width each) were installed in the unit in Casel. Six plates (50 $\mathrm{mm}$ in length and $60 \mathrm{~mm}$ in width each) were installed in Case2.

尖端流が増加するが, 真空槽内の圧力が $300 \mathrm{~Pa}$ より高く なるにつれ熱先端流が，徐々に弱まることによるものと 考えられる.
今回の実験では真空槽内圧力 $300 \mathrm{~Pa}$ 付近で圧力上昇 が最大となっているが，これは今回用いた装置に固有の ものであり，一般に熱尖端流を用いた送風器あるいはポ ンプがこの圧力で最大効果を出すものではない：たとえ ばエッジの鋭さ (曲率) あるいはプレートの上下間隔な どによって異なると考えられる。

図 2 の温度記録からプレートの両縁では約 $90^{\circ} \mathrm{C}$ 温 度差があり，この温度差によりプレートに沿う熱まふくく 流が生じているものと考えられる.ここで提案した送風 器は，特に熱玉ふく流を効果的に利用することを目指し たものではなく，特に温度公配を大きくするような配虑 はしていない：ただ一般的にクヌッセン数 Kn（気体分 子の平均自由行程/系の代表長さ）が小さいとき，すな わち真空の圧力がそれほど低くないときには，熱まふく 流の大きさは Knに比例し，熱尖端流は $\mathrm{Kn}^{1 / 2}$ に比例する とされており (6)，クヌッセン数 Kn が小さいときには 熱まふく流よりも熱尖端流汃卓越する. 曽根らの熱まふ く流の実験 (1) (6) でも，系の代表長さはわれわれのも のと同様 (cm オーダー) で真空度は数 $\mathrm{Pa}$ から数十 $\mathrm{Pa}$ て熱まふく流が顕著にあらわれており，今回提案した送 風器の効果か影著となる $300 \mathrm{~Pa}$ においては，熱尖端流が 卓越していると考えられる.

また, Case 1 と Case 2 の上昇圧力を比較すると Case 2 の上昇圧力は Case 1 の2 倍程度あり, プレートの取り付 け枚数を増やすことにより熱尖端流を高めることができ る.

2-3-3 流速 熱尖端㐬を利用した送風器により生 じる気流の流速は，装置の構造は異なるが緒言で述べた 杉元らの数值解析 (6) (7) で怯，約 $30 \mathrm{~m} / \mathrm{s}$ の気流力゙得ら れており，われわれの装置においてもほほ同程度の気流 が得られるものと考えられる。

\section{3. 熱尖端流を用いた送風器による凍喆乾燥実検}

熱尖端流を利用した送風器により発生する気流によ り, 凍結物の乾燥力促進されることを直接陮認するため, 真空槽内に送風器を設置して乾燥実験を行う.

3-1 実㰸裝置 熱尖端流を生ずるプレートの平面図 およひ断面図を図4に示す．図に示すようにプレートは 長さ $250 \mathrm{~mm}$ ，幅 $120 \mathrm{~mm}$ の銅板（厚さ $0.5 \mathrm{~mm}$ ) に長手 方向に $18 \mathrm{~mm}$ 間隔で 4 箇所の $5 \mathrm{~mm}$ 幅の短冊状の切り込 みと最下端部に $10 \mathrm{~mm}$ 幅の切り欠きを設けた. 断面図に 示すように各切り込み部の一方の縁部は丸く筒状にし， 下端部を丸めた 5 枚の短册状プレートが連続した形状の 板を 1 枚のプレートとした.このプレート 4 枚を $20 \mathrm{~mm}$ 幅の間隔で高さ $120 \mathrm{~mm}$, 橫幅 $250 \mathrm{~mm}$ ，奥行き $90 \mathrm{~mm}$ のアルミ製容器内に納めて送風器を製作した (図5). 


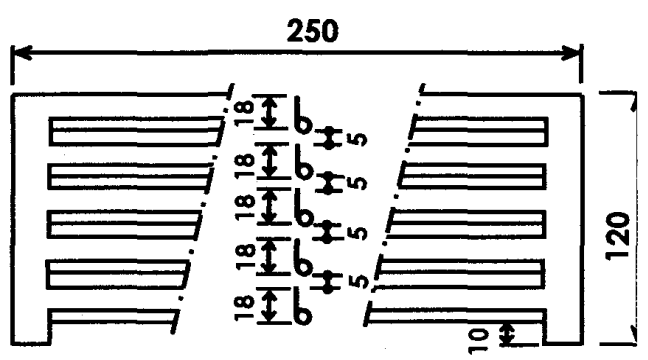

Fig 4 Plate of the blower to induce the thermal edge flow. The plate was made of a copper sheet ( $0.5 \mathrm{~mm}$ in thickness).

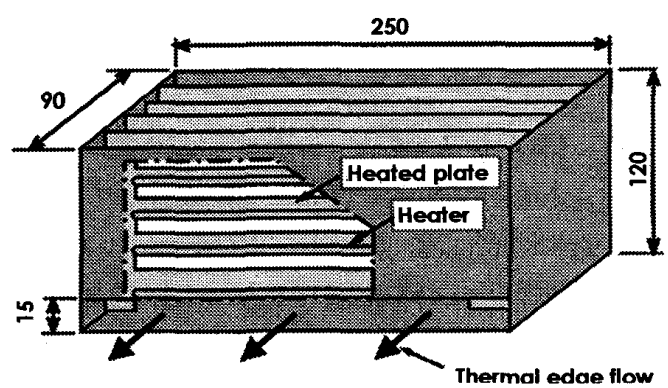

Fig. 5 Diagrammatic illustration of the blower driven by the thermal edge flow. There were four plates to induce the thermal edge flow in the blower.

送風器の吸気口は上部に設け，装置の下部には高さ 15 $\mathrm{mm}$, 横幅 $250 \mathrm{~mm}$ の開口を設けて送風口とした. 各短 冊状プレートの筒状の中空部分には絶縁のために石英管 を挿入し，その石英管の中にプレートを加熱するための ヒーターとしてニクロム線を設けた。

実験に用いる試料は，一辺 $1 \mathrm{~cm}$ 立方体（重量約 $0.09 \mathrm{~g}$ ) のスポンジに約 $0.1 \mathrm{~g}$ の水を含ませ，冷凍凍結さ せたものを用いた。

熱尖端流を利用した送風器を設置する真空槽内の圧力 は次の二つの場合を設定した. Case 1 は真空槽内圧力を 約 $10 \mathrm{~Pa}$ に，またCase 2 は約 $100 \mathrm{~Pa}$ に設定し乾燥実験を 行った. Case 1 の実験には值径 $1 \mathrm{~m}$, 奥行き $1 \mathrm{~m}$, 容積約 $1 \mathrm{~m}^{3}$ の円筒状真空槽を，一方 Case 2 の場合には前述の予 備実験で用いた容積約 $0.09 \mathrm{~m}^{3}$ の矩形犾真空槽を用いた。

円筒真空槽内に熱尖端流を利用した送風器を設置し たCasel の実験状況を図6に示寸，送風器のプレート温 度，送風口の出口前方の温度およひ真空槽内の温度を計 測するために熱電対を設置し，送風器にはプレートの加 熱ヒーターへの電源ケーブルを接続している.

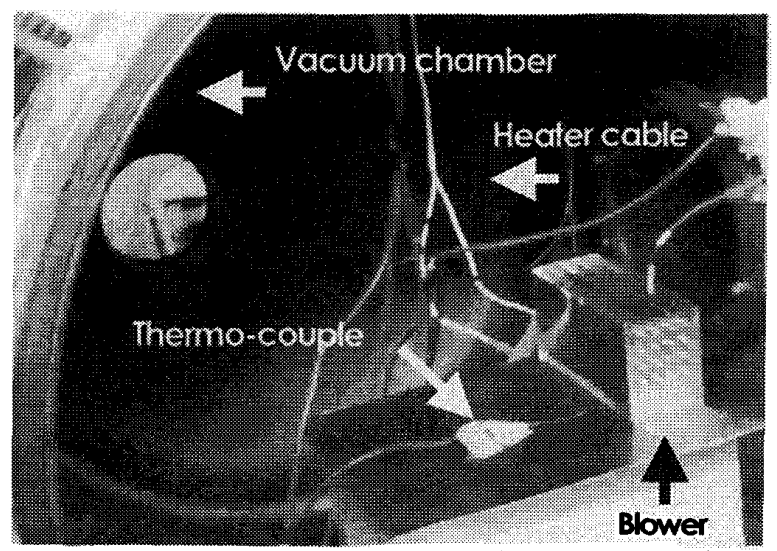

Fig. 6 Test apparatus in the vacuum chamber at the test in the pressure range of $10 \mathrm{~Pa}$. Temperature of the plate of the blower, temperature in front of the ventilation opening of the blower, and temperature in the vacuum chamber were measured by thermo-couples.

3-2 実㰸方法 真空槽内では送風器の送風口前方 にスポンジ試料 2 個を間隔をあけて設置する，送風口の 右側のスポンジは設置位置 1 , 左側のスポンジは設置位 置2として区別する. 各スポンシ試料の重量は実験の開 始前およひ終了後に計測し，その差をスポンシ試料から の昇華水分量とする.

各実験での乾燥时間は，5分間～50 分間で各実験時間 での昇華量を調べる. またCase 1 およびCase 2 の各実験 時間で送風のある場合および送風のない場合の二つのケ 一スの実験を行う。送風のない実験とは，真空槽内に設 置した送風器のヒーター の加熱を行わず，送風機の機 能を停止した場合の実験である.

実験の手順は次の通りである.

(i ) 任意の2個のスポンジ各々に水を約 $0.1 \mathrm{~g}$ 含ま せ, 冷涷庫にて 15 分〜20 分間泠却涷結させる. 冷凍

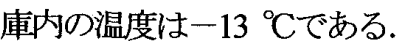

(ii) 試料を泠凍庫から取り出し重量を計測する.

(iii) 2 個の試料を真空槽内送風器の送風口前 $1 \mathrm{~cm}$ に $10 \mathrm{~cm}$ の間隔で設置し真空引きを開始する. 送風器を使用する実験の場合は，真空引き開始と同時 にプレートヒーターの加熱を開始する. ヒーターの加 熱電土は一定に設定する.

(iv) 5 10 分ごとに真空槽内の圧力と温度，プレ 卜温度および送風器出口の温度を記録する。

（v）予定した乾操時間が経過した後加熱を停止し， 真空槽内を復圧し試料を取り出し，試料の重量を計测 し㫒華量を求める.

(i （v)を10回繰り返し, 昇華量の平均值を求める. 


\section{$3 \cdot 3$ 実穃結果及ひ考察}

3.3.1 真空措内の压力 各乾燥時間における真 空槽内の平均圧力を図 7 に示す. 真空槽内の圧力は Case 1 の場合には 10-30Pa の範聿で，また Case 2 の場合には 50-250 Pa の範囲であった. なお、Case 2 の場合には真 空槽に接続する真空配管の抵抗により圧力が下がるのが 遅いため乾燥時間が 5 分の場合には真空槽内の圧力は $260 \mathrm{~Pa}$ と十分に下がっていない.

3.3.2 各部温度卒化 Case 1 の乾燥時間 40 分の 場合における真空槽内の温度, プレートの温度, および 送風器出口前の温度の時間変化を図 8 に示寸. 40 分経過 した実験の終了時にはヒーターを設けたプレート部の温 度は $240{ }^{\circ} \mathrm{C}$ 送風器出口前の温度は $70^{\circ} \mathrm{C}$ 上昇してい る. 真空槽内の温度は $25^{\circ} \mathrm{C}$ で上昇はない.

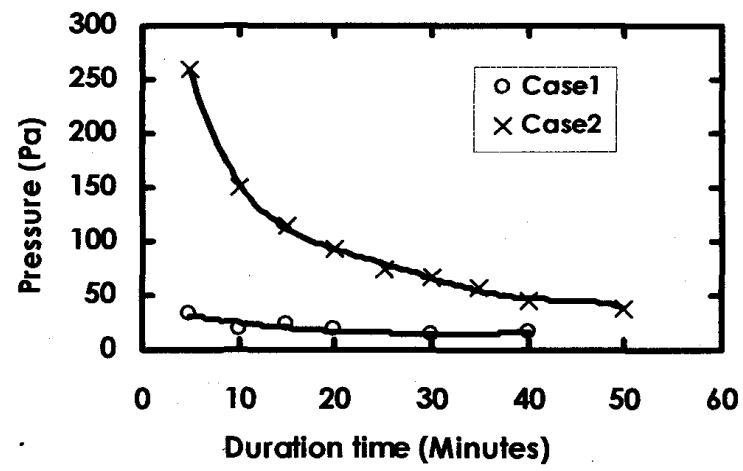

Fig. 7 Average pressures in the vacuum chamber of each experiment in the pressure range of $10 \mathrm{~Pa}$ (Case1) and in the pressure range of $100 \mathrm{~Pa}$ (Case2).

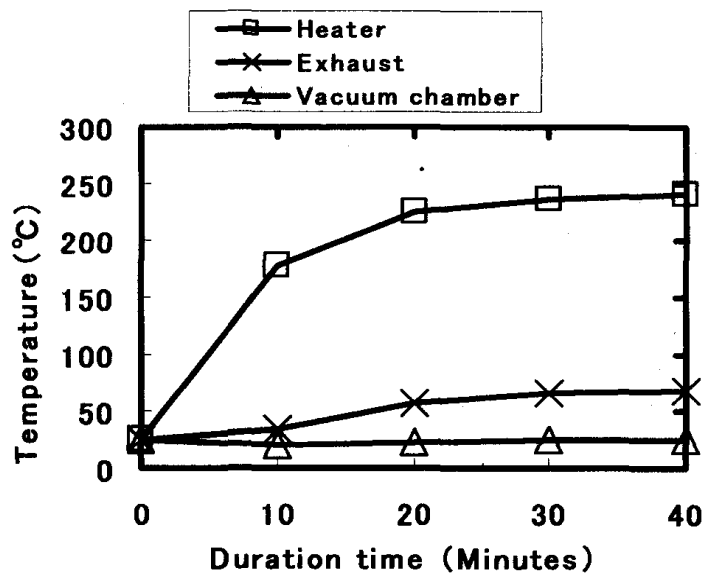

Fig. 8 Temperature histories at (1) heater of plate, (2) in the vacuum chamber, and (3) in front of the ventilation opening during the test of 40 minutes drying time at the pressure range of $10 \mathrm{~Pa}$.
送風器を用いない 場合には真空槽内の温度, プレート の渴度および送風器出口前の温度は $20-25{ }^{\circ} \mathrm{C}$ て温度 の上昇はない

3-3-3 スポンジの残水率 スポンジの残水率は, 実験の前にスポンジに加えた水 (平均約 $0.1 \mathrm{~g}$ ) に対し乾 燥実験の終了後にスポンジに残った水の割合をパーセン テージで示す. Case 1 の場合でスポンジの設置位置 1 お よひ設置位置 2 での残水率を, 乾燥时間ごとに図9に示 す. 本図に見るように試料の設置位置による残水率の違 い性見られない：これは送風口から送りだされる熱尖端 流に偏りが少ないことを示している.

$3 \cdot 3 \cdot 4$ 熱尖端流を用いた送風器の有效栍 各乾 燥時間におうける設置位置 1 およひ設置位置2を合わせた 総スポンジの残水率の平均值をCase 1 およびCase 2 につ いて図 10 に示す。

本図には, Case 1, Case 2 の各場合で送風器を作動さ せない場合，および送風器を作動させた場合を示す。送 風器を用いない場合には，Case 1 およびCase 2 い゙れの 場合にも, 乾燥時間 40 分を経過してもスポンジ内に水が 残るが，送風器を用いた場合には Case 1 およびCase 2 い ずれの場合にも, 乾燥時間40 分でスポンジはほほ乾燥す る. 送風の有無による乾燥の違、は，残水量が少なくな るにつれて，すなわち乾燥の終段階こおいてより顕著に なっている. Case 1 で残水率 10 \%に達するためには, 送風がない場合には約 20 分の乾燥时間が必要であるが, 送風のある場合には約 15 分でこの残水率に達する. 同样 に残水率 $5 \%$ の場合には送風のない場合には約 40 分の乾 燥時間が必要なのに対し送風のある場合には約 20 分で 到達しており，送風器を用いることで乾燥し必要な時間 は, 送風器を用いない場合のほぼ半分となる。

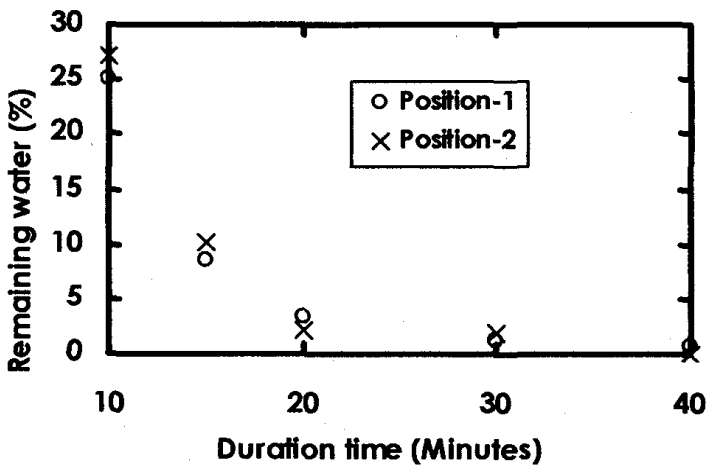

Fig. 9 Remaining water ratio of sponges on the right side of ventilation opening (positionl) and on the left side of ventilation opening (position2) at the pressure range of 10Pa in case of test using the blower driven by the thermal edge flow. 


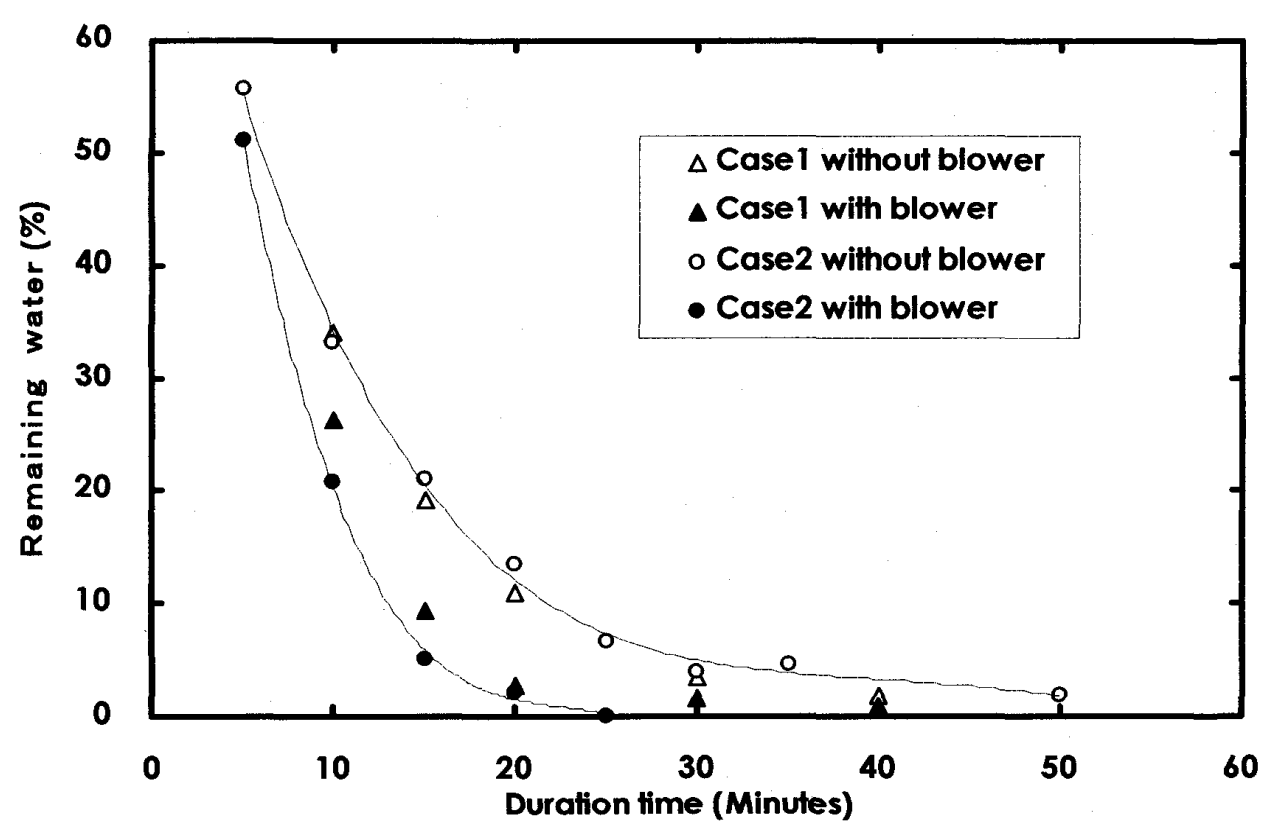

Fig. 10 Remaining water ratio versus drying time in the case of the pressure range of 10Pa (Case 1) and that in the case of the pressure range of $100 \mathrm{~Pa}$ (Case 2), and the comparison of the results between the experiments using the blower (filled symbols) and those without the blower (unfilled symbols). In the case of without the blower, the heaters attached to the plates are simply switched off so that there is no thermal edge flow induced.

Case 1 および Case 2いずれの場合にも熱尖端流を利 用した送風器を用いた場合の方が, 送風器を用いない 場合に比べてスポンジの乾燥が早いことから, 本送風 器が凍結されたスポンジからの昇華・乾燥に効果的で あることがわかる。

3・3-5 真空指内の圧力の影䇺 送風を用いな い場合には, 乾燥時間 15 分および 20 分では, 残水率 は Case 1 の場合が Case 2 に比べわずかに少ない.これ は真空槽内圧力が低い場合に乾燥が早く進むというよ く知られた事実を表している.

一方, 送風器を用いた場合には, 送風器の無い場合 とは逆にCase 2 の場合が Case 1 の場合に比べ同じ乾燥 時間では残水率が少なく乾燥の進みが早い. Case 2 の 場合には, 25 分の乾燥時閒で残水率はほぼ $0 \%$ となる が, Case 1 の場合では 40 分の乾嬠時間が必要になる. このことから真空槽内の圧力が Case 1 の低圧力域より も Case 2 の高圧力域で熱尖端流を利用した送風器が凍 結乾燥の促進により効果的に働くことが分かる.

今回実験した二つの圧力域での熱尖端流による凍 結乾燥への効果は圧力が高い場合の方がより有効であ り，この傾向は前節の予備実験での上昇圧力の傾向と 同じである.この事実は, 提案した送風機により, 冷 凍乾嬠に用いる真空槽の圧力を低く設定する必要がな
いこととなり，用いる真空ポンプの負荷を軽減しうる ことを示している。

\section{4. 結 語}

本研究では熱尖端流を利用した送風器による気流の 発生を, 容器内下流部の圧力の上昇により確認し, ま た凍結させたスポンジ試料を用いて，同送風器が凍結 乾燥の促進に有効であることを確認した。凍結乾燥に おいては, 稼働圧力により送風器の促進効果に違いが あることを確認したが，送風器は，食品の乾燥に用い られる圧力域から医薬品などの分野で用いられる圧力 域までの範囲で, 被凍結物の乾燥に効果的であること が明らかになった。

なお、この熱尖端流はプレートに固有のエッジの鋭 さ（曲率）あるいはプレートの上下の間隔などによっ ても影響があるものと考えられる. 今後これらの影響 を確認し送風器の改良を行うとともに，熱尖端流を利 用した送風器を実機の凍結乾燥装置に組み込みその効 果の確認を行う.

以下に結果の概要を記す.

1. 一端を開放した容器に一方の縁を丸く筒状に曲 げたプレートを複数枚取り付け真空槽内に設置し,こ のプレートを加熱することで容器内下流部圧力の上昇 を確認した. 
圧力の上昇は真空槽内の圧力が高くなるにつれ上昇 し 200-400 Pa の領域で顕著に認められた。

2. 熱尖端流を利用した送風器の凍結乾燥への利用 実験で, 送風器を利用することにより凍結乾燥に要す る時間がほぼ半減した。

3. 熱尖端流を利用した送風器の凍結乾燥での稼働 圧力として $10 \mathrm{~Pa}$ 程度の圧力域の場合よりも $100 \mathrm{~Pa}$ 程 度の圧力域での場合が送風器の乾燥促進効果が大きい.

本研究の一部は財団法人内藤泰春科学技術振興財 団からの助成金によりなされた。ここに記して謝意を 表する.

\section{文献}

(1) Sone,Y., Aoki,K., Molecular Gas Dynamics, (1994), Asakura. (in Japanese)

(2) Sone,Y., Waniguchi,Y., Aoki,K., One-way flow of rarefied gas induced in a channel with a periodic temperature distribution, Phys.Fluids, (8), (1996), pp.2227-2235.

(3) Sone,Y., Sugimoto,H., Vacuum Pump without a Moving Part and its Performance, in Rarefied Gas Dynamics, (A.D.Ketsdever and E.P.Muntz), (AIP, New York,2003) , pp.1041-1049

(4) Sone,Y., Yoshimoto,M., Demonstration of rarefied gas flow induced near the edge of a uniformly heated plate, Phys.Fluids, 9(11), (1997), pp.3530-3534.

(5) Sone,Y., Kinetic Theory and Fluid Dynamics, (2002), BIRKHAUSER.

(6) Japan Society of Fluid Mechanics ed., Handbook of Fluid mechanics, (1998), Japan Society of Fluid Mechanics .(in Japanese)

(7) Sugimoto,H., Sone,Y., Vacuum Pump without a Moving Part Driven by Thermal Edge Flow, in Rarefied Gas Dynamics, (M.Capitelli), (AIP, New York,2005), pp.168-173

(8) Sugimoto,H., Numerical Analysis of the Rarefied Flow in a Vacuum Pump Driven by Thermal Edge Flow, J.Vac.Soc.Jpn. Vol.49, (2006), pp.481-487. (in Japanese)
(9) ULVAC,Inc., Handbook of Vacuum, (2006), Ohosha, Ltd. (in Japanese)

(10) Takano,T., Tadano,T., Drying of food industries, (1968), KORIN publishing Co., Ltd. (in Japanese)

(11) Matsuno,R., et al., Concentration and drying, (1988), KORIN publishing Co., Ltd. (in Japanese)

(12) The Japan Society of Mechanical Engineers ed., Flow of atom and molecule, (1996), Kyouritsu Shuppan Co.,Ltd. (in Japanese) 